\title{
Optimal Capital Structure for a Property-Liability Insurer
}

\author{
Stephen P. D'Arcy ${ }^{\mathrm{a}}$ and Teresa Lwin ${ }^{\mathrm{b}}$ \\ ${ }^{a}$ Mihaylo College of Business and Economics, California State University Fullerton, 800 North State College \\ Blvd, SGMH-5113, Fullerton, CA 92834-6848, U.S.A. \\ E-mail: s-darcy@uiuc.edu \\ ${ }^{\mathrm{b}}$ Department of Finance, University of Chicago Booth School of Business, 5807 South Woodlawn Avenue, \\ Chicago, IL 60637, U.S.A. \\ E-mail: teresalwin@chicagobooth.edu
}

Traditional finance studies have found that firm value is maximised at a mid-range level of leverage. This paper empirically tests the effect of leverage on firm value for property-liability insurers. We analysed an international data set of 96 insurers from 1992 to 2006 using two measures for firm value (price-to-earnings and market-to-book) and three measures of leverage (liabilities-to-equity, premiums-to-equity and surplus duration). We found that price-to-earnings at first increases with leverage, as measured by liabilities-to-equity and premiums-to-equity, but decreases past a certain point. Market-to-book exhibited a similar pattern for the premium-to-equity ratio but had a positive relationship with liabilities-to-equity and a negative relationship with surplus duration.

The Geneva Papers (2012) 37, 509-538. doi:10.1057/gpp.2012.25

Keywords: capital structure; leverage; firm value

\section{Introduction}

Past finance research shows that imperfections in the market make capital structure a significant determinant of firm value. However, unique characteristics of propertyliability (P-L) insurers may change the relationship between capital structure and firm value. Our study seeks to determine whether capital structure significantly impacts P-L insurers' value, and consequently whether management of P-L insurers should focus on capital structure issues.

The first section of this paper reviews past capital structure literature, both in general and for P-L insurers, that motivates our models and tests. The paper then focuses on the empirical study, beginning with the basic relationship between leverage variables and measures of firm value. The empirical study incorporates several components of capital structure other than leverage and expands on the basic relationship between capital structure and firm value by including the impact of other significant value drivers including return on total equity (ROTE). We also discuss how segmenting the data set into U.S. and international insurers significantly changes the regression results. The final section of the paper provides hypotheses to explain the empirical findings and conclusions for management of P-L insurers. 


\section{General capital structure literature}

\section{Capital structure effects in a perfect world}

Before undertaking an analysis to determine the optimal capital structure for insurers, a pertinent question is whether capital structure affects the value of insurers at all. ${ }^{1}$ In fact, Modigliani and Miller showed that the value of a firm is determined by its assets, and is unaffected by capital structure - in perfect markets. The finding is based on the premise of conservation of value; an asset's value should be independent of any claims against it. This idea extends beyond leverage ratios to which types of debt and equity securities to issue. The value of the firm will be unaffected as long as changes in capital structure do not affect investors' choices.

Capital structure changes do not affect investor choice because investors can replicate capital structure changes on their own account (assuming that they can borrow at the same rate as the corporation). In addition, even though some types of securities a corporation might issue are advantageous for certain investors, they can be replicated by other companies. Consequently, these securities do not affect the value of the firm in efficient markets. Additional support for the theory that capital structure has no effect on firm value comes from the offsetting movements of risk and return when the leverage of a firm increases. As leverage increases, the expected return to equity investors increases but so does the volatility in returns to equity investors (the equity beta increases). This result holds when return on assets and the beta of assets are assumed to stay constant as the leverage ratio changes. ${ }^{2}$

\section{Imperfections that make capital structure significant}

Since markets are not perfect, the next question is whether market imperfections make capital structure a driver of firm value. Imperfections that may play a role in the capital structure decision are: taxes, the cost of financial distress, the effect of leverage on managerial incentives, costs to enforce debt contracts, and the lack of perfect information. We will discuss the two most important theories describing the capital structure decision; the trade-off theory, resulting from taxes and the cost of financial distress, and the pecking order theory, arising from information asymmetry between owners and managers.

The importance of imperfections can be seen simply by adding taxes to a perfect market. The ability to deduct interest payments as expenses provides a tax shield for corporations that issue debt. Assuming a firm maintains a steady level of debt and is able to issue debt at a constant interest rate, the amount of the tax shield will depend only on the company's tax rate, whether it has enough income to use the tax shield, and its ability to pay the interest on the debt. The corporate tax rate has historically been fairly stable, so management can reasonably accurately predict savings from

\footnotetext{
${ }^{1}$ Brealey et al. (2006, pp. 445-496) provide a synopsis of general capital structure theory. Additional sources with more in-depth analyses will be cited here.

${ }^{2}$ Modigliani and Miller (1958).
} 
deducting interest payments. If a firm does not have enough income in one year to use its tax shields, the tax shields can usually be applied to past or future tax returns. Thus, the main risk factor when predicting tax savings is a company's ability to make interest payments.

How do tax savings from debt affect the value of the firm? A firm's after-tax assets equal its liabilities plus equity. Pre-tax assets equal debt and equity plus the present value of future taxes. Consequently, anything that can be done to reduce taxes, the government's claim, will increase the firm's after-tax assets. If we assume that the firm's value is independent of its capital structure, except for the effect of tax shields, then the value of a debt issuing firm would simply be its all-equity value plus the present value of the tax shield. This relationship implies that the optimal debt-equity mix would be 100 per cent debt to maximise the tax shield. ${ }^{3}$ However, higher personal tax rates on interest income work to offset the firm tax savings once all investors are considered, not just shareholders. ${ }^{4}$ Other market imperfections also work to reduce the optimal level of debt.

The cost of financial distress motivates firms with a strong capital position to reduce their leverage. Bankruptcy costs can be considerable. Legal and court fees get paid before lenders do, so lenders demand a higher return from companies that are more likely to default. The higher return for debt holders reduces the return that would otherwise go to stockholders. Even if a firm does not go bankrupt, financial distress is costly. A firm in financial distress may have to pay more to recruit top employees, customers might be wary of purchasing products (especially if they require future servicing), and suppliers might require cash payments and have a disincentive to provide good service. ${ }^{5}$ However, poorly capitalised firms have an incentive to accept higher volatility in results to exploit the option value of default.

Conflicts of interest between debt and equity holders and between owners and managers add agency costs in times of distress. Managers acting on their own behalf can take actions to improve their own compensation (engaging in excessively risky behaviour) or to protect their jobs (avoiding potentially profitable risks) to the detriment of the owners. Alternatively, managers acting in shareholders' interests might be more willing to take on risky, negative net present value projects, because more of the losses accrue to debt holders than shareholders. Conversely, managers might not invest in safe, positive net present value projects because issuing new shares to raise funds might dilute value for shareholders. ${ }^{6}$ Another manifestation of this incentive mismatch is in the willingness to issue dividends. The market value of the firm's stock doesn't decrease as much as usual when dividends are issued in times of distress. Instead, the market value of the debt decreases more significantly because the decrease in cash makes the debt riskier. ${ }^{7}$ Higher leverage increases the likelihood that a firm will incur agency costs so investors reduce the market value of a firm as leverage increases. Lenders incur monitoring costs in an attempt to keep management from

\footnotetext{
${ }^{3}$ Modigliani and Miller (1963).

${ }^{4}$ DeAngelo and Masulis (1980).

${ }^{5}$ Robichek and Myers (1966), Jensen and Meckling (1976).

${ }^{6}$ Jensen and Meckling (1976).

${ }^{7}$ Myers (1984).
} 
making poor decisions due to a conflict of interest and require a higher rate of return to offset these costs. ${ }^{7}$ These provisions can be even more costly when they constrain management's ability to make good investment decisions.

The costs of financial distress will vary by firm and industry. The amount that can be salvaged and paid to lenders in bankruptcy depends on the nature of the assets a firm holds. Companies with mostly intangible assets will be able to recover very little, while companies with real assets such as commercial real estate may be able to salvage a large percentage of their value. Furthermore, intangible assets and high growth projects reduce the effectiveness of measures creditors take to monitor managers or restrict managers from putting stockholders' interests above that of creditors. If firms hold less debt, they will reduce the associated agency costs. ${ }^{8}$ Industry- and firmspecific factors are evident in the conservative financing of firms whose value relies mostly on research and development or human capital. ${ }^{9}$ Despite the validation of the theory that capital structure decisions rely on the trade-off of increased firm value due to tax shields and decreased firm value from financial distress and agency costs (the trade-off theory), there are many firms that do not fit this theory. Based on the tradeoff theory, more profitable firms should be more highly leveraged, because they have high earnings against which a tax shield could be used, and an ability to hold large amounts of debt. In practice, many profitable firms have low debt to equity ratios. In addition, debt ratios have not increased in periods with high corporate tax rates and are not higher in countries with high taxes. ${ }^{10}$

An additional imperfection, information asymmetry between managers and investors, leads to the pecking-order theory, which can help explain why profitable firms often have very little debt. The pecking-order theory indicates that firms prefer to raise capital by using internal finance, then various types of debt and finally, as a last resort, equity. Consider a company with good growth opportunities and a good outlook that needs to raise capital. The company won't want to use equity financing because investors do not know the extent of the company's opportunities and would not pay as much as the managers think the stock is worth. However, a company with a poor outlook will not issue stock to raise capital because investors may take the issue as a signal that managers think the stock is overvalued. A debt issue delays the release of bad news to investors. As a result of information asymmetry, companies will tend to favour new debt issues over new issues of stock. In some cases, such as high-growth companies whose intangible assets would make financial distress particularly costly, investors will not automatically perceive stock issues to be bad news. Companies can maintain lower debt ratios by using internal financing, which explains the low debt ratios of profitable companies that can rely on internal funds. ${ }^{11}$

The pecking order theory explains why equity issues are rare. However, the pecking order and trade-off theories don't fully explain another trend; smaller, newer

\footnotetext{
${ }^{8}$ Myers (1977).

${ }^{9}$ Long and Malitz. (2006).

${ }^{10}$ Brealey et al. (2006).

${ }^{11}$ Myers (1984), Myers and Majluf (1984).
} 
companies tend to issue stock more than debt to raise capital. This trend is due to another market imperfection; small, new companies do not have the same open access to public bond markets as larger, more established companies. ${ }^{12}$

As a result of the different effects of market imperfections, the optimal capital structure for firms varies based on a number of factors, and is generally found to be at a mid-range level of leverage. Increasing leverage beyond that point will tend to reduce the value of the firm. In this paper we will test the hypothesis that insurers select capital structures that maximise firm value.

\section{Imperfections for insurers}

Since it is widely accepted that capital structure can impact firm value due to market imperfections, it would make sense for insurers to manage their capital structures to maximise firm value. However, given the unique characteristics of insurers, we must consider how capital structure theory applies to insurance; in particular whether imperfections are amplified or diminished for insurers.

Insurers have two types of liabilities, policyholders' claims and debt. Reserves for unpaid losses and loss adjustment expenses are the largest component of a P-L insurer's balance sheet. ${ }^{13}$ The tax shield effect is complex, although it should work in a manner similar to that of other industries. Depending on the country of domicile, either all, or a portion, of these reserves can be deducted from pre-tax income.

The cost of financial distress for a firm depends largely on liquidation value upon bankruptcy. A large portion of insurers' assets are marketable securities, which can easily be valued and sold. On the other hand, insurers have a significant asset, their renewable book of business, which is not explicitly valued as an asset on their financial statement. Owing to the ageing phenomenon, a strong renewable book of business provides an insurer with increasingly profitable repeat policyholders. ${ }^{14}$ This value could be lost in the event of a bankruptcy. Financial distress also affects ratings. Ratings downgrades and other signs of financial distress can influence employee, supplier and customer decisions. ${ }^{15}$ However, many policyholders do not have to be concerned about the possibility of financial distress or leverage when considering insurers because state guaranty funds in the U.S. and national guaranty funds in most other countries assure claims will be paid, which reduces the cost of financial distress.

Additional agency costs arise for insurers from conflicts of interests between owners and policyholders. The conflict of interest between shareholders and policyholders is similar to that between shareholders and lenders; shareholders will want to increase the value of their claim to the firm even if it increases risk for policyholders. Consequently, policyholders may not be willing to pay as much in premiums due to the risk of management putting shareholders' interests first. ${ }^{16}$

\footnotetext{
12 Frank and Goyal (2003).

${ }^{13}$ Staking and Babbel (1995).

${ }^{14}$ Cohen (2008), D'Arcy and Doherty (1990a, b).

${ }^{15}$ Cummins and Doherty (2002).

${ }^{16}$ Mayers and Smith (1988).
} 
Information asymmetries are significant for managers and investors of insurers. For example, the risk of receivables from re-insurers and agents is not transparent to investors. Furthermore, managerial knowledge of the value of loss and loss adjustment expense reserves (which account for about 65 per cent of liabilities) varies greatly from investors' knowledge. Setting loss reserves is a complex process and the information used to calculate the reserves is not usually available to investors. Owing to this information asymmetry, the pecking order theory makes sense for insurers; internal financing is preferred, followed by leverage and then equity. Because of the preference for internal funds, insurers exhibit dividend "stickiness". Insurers are reluctant to pay out capital because it is costly to raise new capital when it is needed (in a period of losses). Of the capital accumulation during the 1990s by the P-L insurance industry, only one-sixth of this was new capital, supporting the pecking order theory. ${ }^{15}$ Insurers with shorter-tail claims have more certain reserves, so they would be able to issue equity with less information asymmetry problems. ${ }^{17}$

Many publicly traded stock insurers in the U.S. are organised as holding companies, with an average of four subsidiaries. These holding companies issue financial debt and equity. One reason for this structure is that insurers' debt issues are highly regulated. Regulators must grant permission for insurers to issue new debt and the debt must be junior to policyholders' claims. As a result, the cost of debt capital is higher for an insurance company than for a holding company with insurance subsidiaries and the holding companies will be more likely to finance with debt. ${ }^{18}$

Another way for an insurer to increase leverage is to write more insurance policies. However, issuing policies is itself costly. To expand in a market requires accepting lower quality applications, increasing advertising, commissions or other selling expenses or lowering the price. Expanding into a new market involves search costs, developing new contracts and additional staffing. These "frictions" limit the flexibility of insurers to make changes in capital structure.

The most relevant capital structure optimisation research for insurers is a Staking and Babbel study to determine the effect of interest rate sensitivity and leverage on the market value of P-L insurers. Staking and Babbel used a modified Tobin's q ratio (market value of equity to market value of tangible assets minus the present value of liabilities) as their variable to represent franchise value. Their hypothesis (which was supported by the study) was that the trade-off between the increased probability of financial distress and increased tax benefit would create an optimal leverage (assets/ capital) point at a moderate level of leverage. ${ }^{19}$

In addition to considering the optimal leverage level, Staking and Babbel also looked for an optimal amount of interest rate risk, as measured by surplus duration. However, they did not find that the optimal approach was to have a mid-range level of interest rate risk. Instead they found that firm value was maximised for either very low or very high levels of interest rate risk. Staking and Babbel hypothesized that this relationship resulted from two types of insurers in the data set: those with low interest

\footnotetext{
${ }^{17}$ Cummins and Nini (2002).

${ }^{18}$ Cummins and Lamm-Tennant (1994).

${ }^{19}$ Staking and Babbel (1995, 1997).
} 
rate risk and high franchise value (i.e. book of business, reputation, state licenses) for whom increasing interest rate risk would be costly, and those with low franchise value and little to lose from increasing volatility and risk from interest rate exposure. Inexplicably, though, most insurers were found to have a surplus duration in the range where the value of the firm was minimised, not maximised. Taking both interest rate risk and leverage into account, company value should be maximised at a moderate level of leverage and either at very low or very high levels of interest rate risk. ${ }^{19}$

\section{Empirical study}

\section{Data set and methodology}

As the value of an insurer can only be determined for publicly traded insurers, our data set was restricted to publicly traded P-L insurers. We obtained most of our data from Compustat Global, which includes both international and U.S. companies - a total of 96 for the market-to-book regressions and 95 for the price-to-earnings regressions. ${ }^{20}$ All data points were converted to U.S. dollars at the then current exchange rates. Our basic model included data from 1992 to 2006 and treated each company and year as a separate data point. The time period was chosen in an attempt to maximise the number of data points we could include while still having a reasonable percentage of companies with data each year (see Appendix A, Table A.1). We excluded data points with negative values for market-to-book or price-to-earnings. We also excluded all data points with values for any of the variables above or below four standard deviations away from the mean in order to eliminate extreme outliers that would skew the results, yielding data sets with 856 observations for the market-to-book regressions and 780 observations for the price-to-earnings regressions (see Table 1).

We used linear regression models to test the effect of non-linear leverage variables on measures of market value by regressing on polynomials of the independent variables. We tested models using two scaling factors for market value-both market value to income (price to three-year trailing average earnings) and market value to shareholders' equity (market-to-book). We tested the effect of a financial leverage measure, liabilitiesto-equity, and a measure of leverage used for insurers, premiums-to-equity.

\section{Leverage results}

Both the first and second orders of premiums-to-equity and liabilities-to-equity were significantly correlated with price-to-earnings at the 5 per cent level. Both first-order measures of leverage were positively correlated with the price-earnings ratio, while the second-orders were negatively correlated (see Table 2). Figures 1 and 2 depict the regression models and actual data points. These regression models indicate that there is an optimal level of premiums-to-equity (4.02) and liabilities-to-equity (8.58), both well above the mean values in the sample. A regression including the first and second orders of liabilities-to-equity and premiums-to-equity together has a significant

\footnotetext{
${ }^{20}$ Best's Aggregates and Averages (2007).
} 
Table 1 Descriptive statistics

\begin{tabular}{|c|c|c|c|}
\hline Variable & Average & Standard dev. & $N$ \\
\hline Liabilities to equity & 3.861 & 3.444 & 856 \\
\hline Liabilities to equity ${ }^{\wedge} 2$ & 26.757 & 54.729 & 856 \\
\hline Premiums-to-equity & 1.423 & 1.560 & 856 \\
\hline Premiums-to-equity^${ }^{\wedge} 2$ & 4.454 & 16.176 & 856 \\
\hline Return on total equity & 0.100 & 0.103 & 856 \\
\hline Size $\ln$ (assets) & 7.679 & 2.348 & 856 \\
\hline Market-to-book & 1.445 & 1.744 & 856 \\
\hline Price-to-earnings (full) & 20.503 & 100.844 & 856 \\
\hline Price-to-earnings (without negatives) & 21.368 & 22.890 & 780 \\
\hline Surplus duration (set for price-to-earnings regression) & 7.703 & 7.001 & 83 \\
\hline Price-to-earnings (set with duration) & 17.275 & 9.442 & 83 \\
\hline Surplus duration (set for market-to-book regression) & 9.269 & 9.502 & 90 \\
\hline Liabilities to equity (set with duration, market-to-book) & 3.387 & 1.970 & 90 \\
\hline Premiums-to-equity (set with duration, market-to-book) & 1.227 & 0.534 & 90 \\
\hline Market-to-book (set with duration) & 1.582 & 0.483 & 90 \\
\hline
\end{tabular}

Note: All statistics were for the full data set except where noted. The regressions with price-to-earnings were done on a reduced set, which excluded observations with negative price-to-earnings. Original numbers were in thousands, USD.

F-statistic. However the $P$-values for the first and second order of premiums-to-equity were not significant at the 5 per cent level, likely because of multicollinearity resulting from the correlation between liabilities-to-equity and premiums-to-equity. This indicates that liabilities-to-equity dominates premiums-to-equity in its ability to explain price-to-earnings, so the best regression equation for leverage and price-toearnings is:

$$
V_{P E}=11.26+L_{L E} \times 4.47-L_{L E}^{2} \times 0.26,
$$

where $V_{P E}=$ Price-to-earnings, $L_{L E}=$ Liabilities-to-equity.

When tested with market-to-book as the dependent variable, the first order of liabilities-to-equity was again positively correlated with the market value factor (see Figure 3 for the regression line and data points), but when included in a regression with its square, neither order of liabilities-to-equity was significant. The first-order regression had an $R$-square of only 0.01 . Premiums-to-equity had a similar relationship with market-to-book as it did with price-to-earnings, only with a higher maximising level (5.70). Figure 4 illustrates the regression curve with the actual data points. A multiple regression of the first and second order of premiums-to-equity and the first order of liabilities-to-equity was significant as a whole (has a significant F-statistic), and each coefficient had the same directional indication as in the individual regressions. However, the $P$-value for liabilities-to-equity was 0.13 , which again was likely due to multicollinearity (see Table 3). This regression indicates that premiums-to-equity dominated liabilities-to-equity as an important factor. Accordingly, the best leverage equation to describe market-to-book is:

$$
V_{M B}=1.12+L_{\operatorname{Pr} e E} \times 0.32-L_{\operatorname{Pr} e E}^{2} \times 0.03,
$$

where $V_{M B}=$ Market-to-book, $L_{\operatorname{Pr} e E}=$ Premiums-to-equity. 
Table 2 Leverage regressions-dependent variable: price-to-earnings

\begin{tabular}{|c|c|c|c|c|c|c|c|c|c|c|}
\hline Regression & Independent variable & Coefficient & T-statistic & $P$-value & Intercept & $R$-square & Standard error & $F$-statistic & F-value & $N$ \\
\hline \multirow[t]{2}{*}{1} & Liabilities-to-equity & 4.466 & 6.453 & 0.000 & 11.236 & 0.055 & 22.283 & 22.521 & 0.000 & 780 \\
\hline & Liabilities-to-equity` $^{\wedge} 2$ & -0.260 & -5.401 & 0.000 & & & & & & \\
\hline \multirow[t]{2}{*}{2} & Premiums-to-equity & 3.786 & 2.972 & 0.003 & 18.048 & 0.014 & 22.759 & 5.506 & 0.004 & 780 \\
\hline & Premiums-to-equity^ 2 & -0.471 & -3.318 & 0.001 & & & & & & \\
\hline \multirow[t]{3}{*}{3} & Liabilities-to-equity & 4.672 & 5.522 & 0.000 & 12.814 & 0.065 & 22.188 & 13.527 & 0.000 & 780 \\
\hline & Liabilities-to-equity $^{\wedge} 2$ & -0.214 & -3.479 & 0.001 & & & & & & \\
\hline & Premiums-to-equity & -2.524 & -1.603 & 0.109 & & & & & & \\
\hline
\end{tabular}

Table 3 Leverage regressions-dependent variable: market-to-book

\begin{tabular}{|c|c|c|c|c|c|c|c|c|c|c|}
\hline Regression & Independent variable & Coefficient & T-statistic & P-value & Intercept & $R$-square & Standard error & $F$-statistic & F-value & $N$ \\
\hline 4 & Liabilities-to-equity & 0.044 & 2.562 & 0.011 & 1.274 & 0.008 & 1.738 & 6.564 & 0.011 & 856 \\
\hline 5 & Liabilities-to-equity & 0.065 & 1.497 & 0.135 & 1.233 & 0.008 & 1.739 & 3.412 & 0.033 & 856 \\
\hline \multirow[t]{2}{*}{6} & Premiums-to-equity & 0.319 & 3.813 & 0.000 & 1.115 & 0.017 & 1.731 & 7.282 & 0.001 & 856 \\
\hline & Premiums-to-equity ${ }^{\wedge} 2$ & -0.028 & -3.470 & 0.001 & & & & & & \\
\hline \multirow[t]{2}{*}{7} & Liabilities-to-equity & 0.040 & 1.530 & 0.126 & 1.073 & 0.019 & 1.730 & 5.642 & 0.001 & 856 \\
\hline & Premiums-to-equity & 0.234 & 2.327 & 0.020 & & & & & & \\
\hline
\end{tabular}




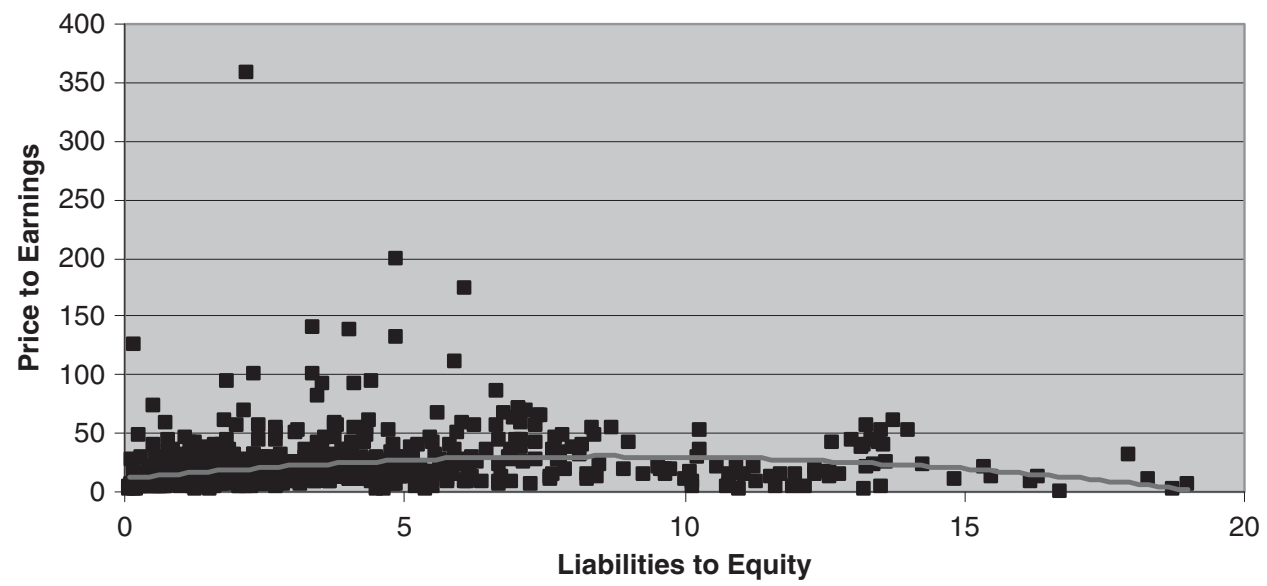

Figure 1. Price to earnings as a function of liabilities to equity.

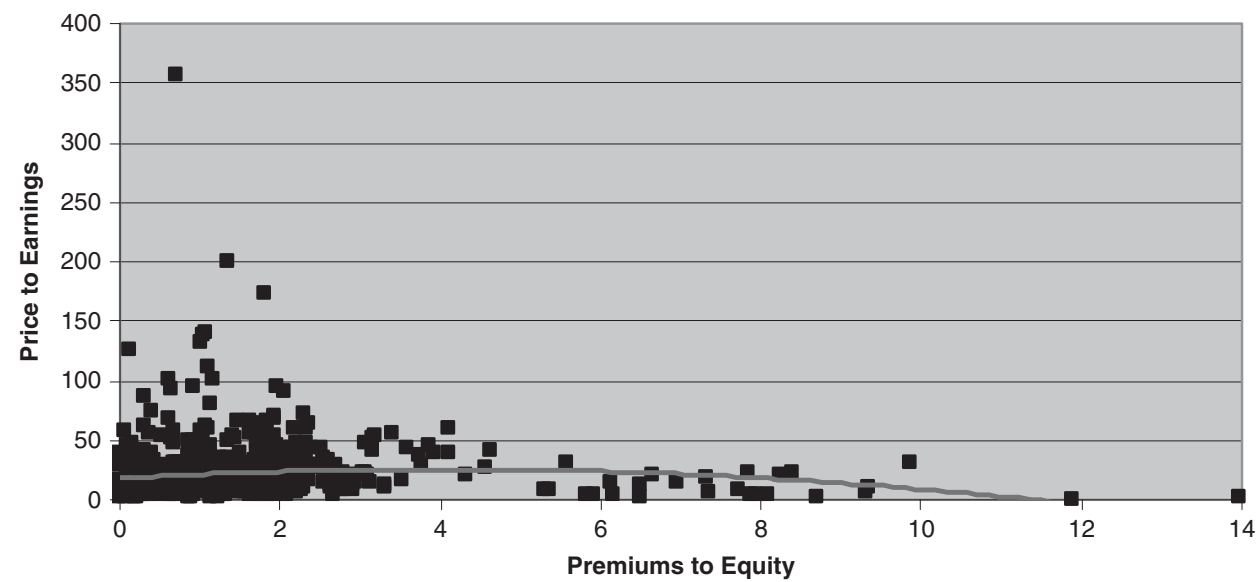

Figure 2. Price to earnings as a function of premiums to equity.

The price-to-earnings and leverage (both liabilities-to-equity and premiums-toequity) and the market-to-book and premiums-to-equity relationships that we found corroborate traditional capital structure theories. Increased leverage is rewarded to a point, but very high levels of leverage will decrease market value. This relationship is likely a result of opposing market imperfections; taxes and the cost of financial distress. The majority of P-L insurers' liabilities are unpaid losses and loss adjustment expenses. Loss reserves, either in full or discounted depending on the country, and interest payments on traditional corporate debt can be deducted from income thus providing a tax shield. However, past a certain point these tax benefits are outweighed by the costs of financial distress, such as bankruptcy and agency costs. 


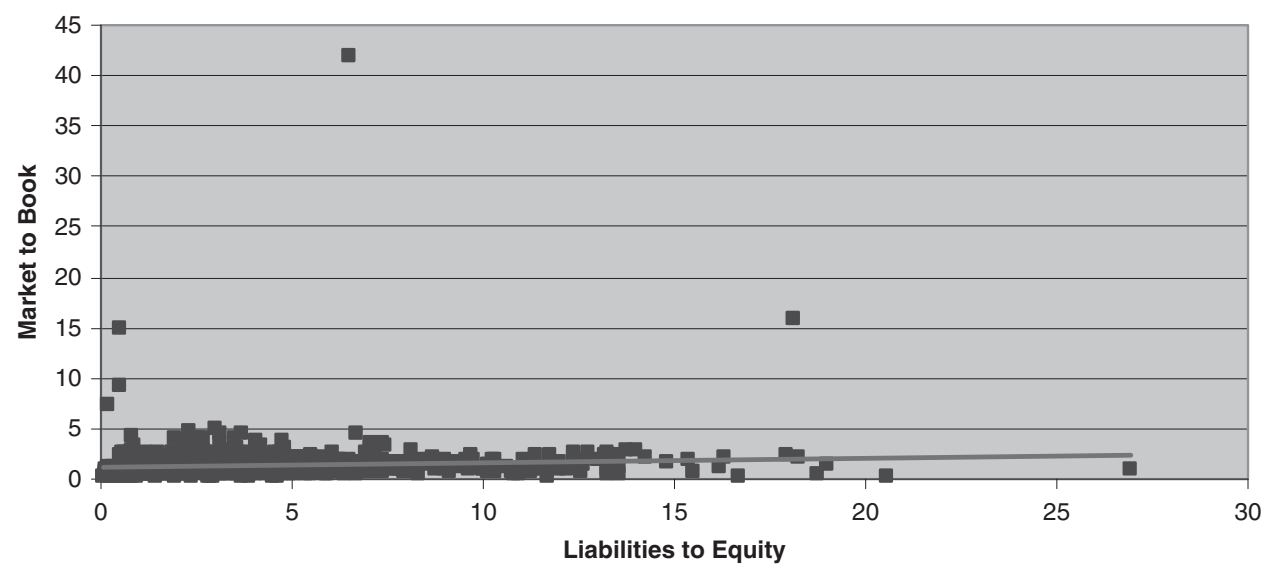

Figure 3. Market to book as a function of liabilities to equity.

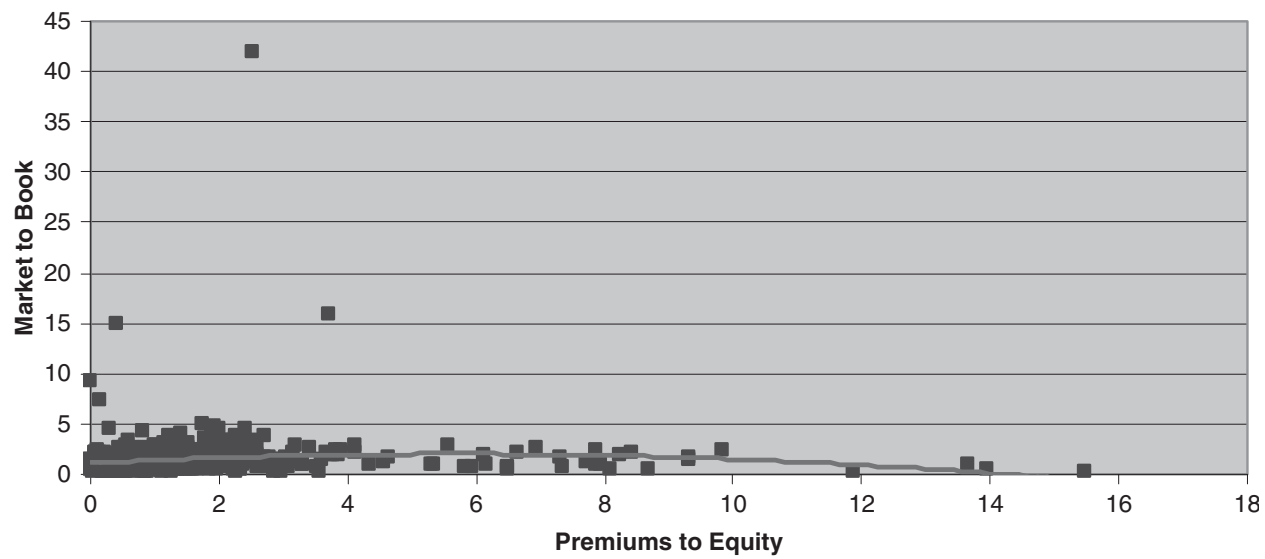

Figure 4. Market to book as a function of premiums to equity.

The only leverage-market value regression which was not significant to the second order was market-to-book with liabilities-to-equity, which had a linear, positive relationship. This finding differs from Staking and Babbel's finding that franchise value (represented by a modified Tobin's q) was significantly correlated to the second order with financial leverage, yielding a maximising level.

Our findings may indicate that liabilities-to-equity is functioning as a proxy for companies with long tail lines. Loss reserves are, in most countries including the U.S., set at nominal values, not the discounted value that would reflect their true economic value. Thus, reserves for losses that will not be paid for a long time are much higher than their economic value, which means that liabilities are overstated and equity is understated. Market-to-book may be an indication that the liabilities-to-equity ratio for long tail lines is recognised to be overstated, rather than a reward for increasing leverage. 
520

Another possibility is that the result is due to differences between countries' accounting standards. In South Korea, insurers can establish contingency reserves for catastrophe losses that have not occurred. Users of Korean insurers' financial statements often combine these contingency reserves with shareholders' equity to create "modified capital", but this adjustment is not included in the total shareholders' equity value provided by Compustat. As a result, Korean companies had 11 of the 15 highest values for liabilities-to-equity and all the 15 highest values for premiums-to-equity. These leverage ratios are higher than they really should be because shareholders' equity does not accurately reflect capital held by Korean firms, which could contribute to the linear relationship between liabilities-to-equity and market-to-book.

\section{Other capital structure components}

In addition to analysing the leverage-market value relationship, we also evaluated the role of other components of capital structure in determining market value. We tested variables representing interest rate risk, liquidity, investment mix, and the level of reinsurance. Investment mix was represented by the ratio of fixed income investment securities to all investment securities and the ratio of equity investment securities to all investment securities. However, neither of these was significantly correlated with either dependent variable. Premiums ceded to total premiums were used to represent the level of reinsurance but it also was not significant. Two measures were tested to represent liquidity. The first was the ratio of cash and short-term investments to total assets to represent the liquidity of all assets. The second was the ratio of investment securities to investment assets to represent the marketability of investment assets. However, both of these factors were not significantly correlated with either market value variable.

We represented interest rate risk with surplus duration. Given the lack of available data and relatively short liability durations of P-L insurers, we assumed the liability durations were zero when calculating surplus duration. Few companies publicise their liability durations; liability durations would have to be extrapolated by determining the weights by line of business for each company and using industry averages. However, little data on premiums by line of business is available. Furthermore, past research has shown that effective liability durations of P-L insurers, when considering the inflation sensitivity of future loss payments, are very short. ${ }^{21}$

Duration is a linear operator, so the duration of a portfolio is the weighted average of the duration of its components: ${ }^{13}$

$$
S \times D_{s}=A \times D_{A}-L \times D_{L},
$$

where $S=$ surplus $(A-L), D_{s}=$ surplus duration, $A=$ assets, $D_{A}=$ asset duration, $L=$ liabilities, $D_{L}=$ liability duration.

We assume $D_{L}=0$, so $D_{S}=(A / S) * D_{A}$ :

$$
A \times D_{A}=E \times D_{E}+B \times D_{B},
$$

\footnotetext{
${ }^{21}$ D’Arcy and Gorvett (2000).
} 
where $E=$ equity investments, $D_{E}=$ equity investment duration, $B=$ bond investments, $D_{B}=$ bond investment duration.

Bond investment duration was taken from company $10-\mathrm{Ks}$, which limited the available data. Many companies did not include this figure or only had it available for recent years. Consequently, we used a much smaller data set (83 compared with 780 for price-to-earnings and 90 compared with 856 for market-to-book) to test duration (see Table 1). Several methods have been used in the past to estimate equity duration. Empirical methods that regress stock price movements on changes in Treasury bond yields produce short equity durations. ${ }^{22}$ Cornell ${ }^{23}$ modified this technique by including the Fama and French factors in the regression.

Owing to data constraints (for example the dividend discount model requires an equity discount rate and constant dividend growth rate), we regressed monthly changes in the S\&P 500 with changes in Treasury bond (10-year) yields to determine equity duration. ${ }^{24} \mathrm{We}$ found rolling 12 -month durations and took the year-end values as the yearly durations. The average equity duration (3.29) was an average of the 12-month durations. The average $R$-square of the 12 month regressions was 0.15 .

Surplus duration calculated using the average equity duration and the yearly equity duration (the corresponding 12-month duration was used for each year, rather than a constant equity duration figure) were highly correlated, with an $R$-square of 0.97 . Consequently, we only used surplus duration with yearly equity duration to capture the differences in percentage of assets in equities between data points in a given year. Surplus duration is negatively correlated with market-to book values, indicating a market penalty for interest rate risk. Surplus duration is not significantly correlated with price-to-earnings (see Tables 4 and 5). A regression including the first and second order of surplus duration yields insignificant $P$-values at the 5 per cent significance level for both terms, although it does have a significant F-statistic (see Table 4).

Our findings differ from those of Staking and Babbel, who found that the coefficient of the surplus duration was negative but the coefficient of the square of the surplus was positive. This difference could be the result of many factors - data from different time periods, different values used for the duration of liabilities, the use of market values compared with book values or because of the small sample of companies in both studies. The Staking and Babbel study included 25 companies from 1981 to 1987 , used adjusted market values for the assets and liabilities and tested the joint effect of leverage and surplus duration. Our market-to-book regression covered 24 companies over the period 1992-2006, but the data was available only for an average of 3.7 years for each company. Staking and Babbel analysed loss payments using the Taylor Separation method that implicitly assumes that all unpaid losses are subject to inflation. Based on their analysis, they did not find convincing evidence that liability

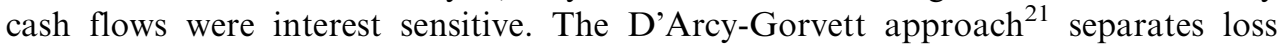
reserves into two parts, one that is fixed in value (repairs that have already been made,

\footnotetext{
22 Brandes Institute (2008).

${ }^{23}$ Cornell (1999).

${ }^{24}$ Treasury yield data was from the St. Louis Federal Reserve site. S\&P 500 close prices were from Yahoo! Finance.
} 
Table 4 Interest rate risk-dependent variable: market-to-book

\begin{tabular}{|c|c|c|c|c|c|c|c|c|c|c|}
\hline Regression & Independent variable & Coefficient & T-statistic & $P$-value & Intercept & $R$-square & Standard error & $F$-statistic & F-value & $N$ \\
\hline 8 & Surplus duration & -0.017 & -3.343 & 0.001 & 1.740 & 0.113 & 0.458 & 11.177 & 0.001 & 90 \\
\hline 9 & Surplus duration & -0.017 & -1.136 & 0.259 & 1.739 & 0.113 & 0.460 & 5.525 & 0.006 & 90 \\
\hline 10 & Premiums-to-equity & 0.117 & 1.226 & 0.223 & 1.438 & 0.017 & 0.482 & 1.504 & 0.223 & 90 \\
\hline
\end{tabular}

Table 5 Interest rate risk-dependent variable: price-to-earnings

\begin{tabular}{|c|c|c|c|c|c|c|c|c|c|c|}
\hline Regression & Independent variable & Coefficient & $T$-statistic & P-value & Intercept & $R$-square & Standard error & $F$-statistic & F-value & $N$ \\
\hline 11 & Surplus duration & 0.206 & 1.392 & 0.168 & 15.687 & 0.023 & 9.389 & 1.938 & 0.168 & 83 \\
\hline 12 & Liabilities-to-equity & 0.747 & 1.041 & 0.301 & 14.994 & 0.013 & 9.437 & 1.083 & 0.301 & 83 \\
\hline
\end{tabular}


medical bills for treatment that have already been rendered) and one that is still subject to inflation (future medical treatments). By surveying companies about the pattern of when losses become fixed in value, they were able to estimate the fixed and variable components. To the extent that loss reserves are sensitive to future inflation, only the variable portion would be affected. Their analysis then shows that the effective duration of total loss reserves approaches zero as the relationship between inflation and nominal interest rates approaches 1. Staking and Babbel determined liability durations to be an average value of 3.47, compared with our assumption that the effective duration of liabilities is zero. The small sample could also have affected our results because premiums-to-equity was no longer significantly correlated with market-to-book and liabilities-to-equity was not correlated with price-to-earnings (see Tables 4 and 5). Regardless of the reasons for the different findings, this work should encourage future research on this area.

\section{Introduction of controls}

Past capital structure research has found profitability to be correlated with leverage. Cummins and $\mathrm{Nini}^{17}$ found over-capitalisation in the P-L insurance industry to be negatively correlated with return on equity (an optimal capital structure was found to achieve cost efficiency). In addition, the pecking order theory implies that profitability affects leverage levels. Consequently, we introduced ROTE as a control factor and found that ROTE was positively correlated with market-to-book and negatively correlated with price-to-earnings (ROTE implies high earnings, which increases the denominator of the price-to-earnings ratio). The addition of ROTE to the leverage regressions only slightly changed the magnitude of the coefficients (see Appendix B, Tables B.1, B.2). ROTE was negatively correlated with liabilities-to-equity (as the pecking theory would imply), but was not significantly correlated with premiums-toequity (see Appendix B, Tables B.3, B.4).

We tested other control factors including size (ln(assets)), variability (standard deviation of income), growth (3-year growth of market value, income and ROTE were tested). However, we found that the only other significant control was size. The first order of size was positively correlated with market-to-book and the second order was negatively correlated. While size does not significantly change the regression with market-to-book and premiums-to-equity, the t-statistic for liabilities-to-equity was not significant in its regression with market-to-book once size was added. However, the F-statistic was significant (see Appendix C, Table C.1). Only the first order of size was significantly correlated to price-to-earnings. Additionally, when size was regressed with premiums-to-equity on price-to-earnings, the t-statistic for both orders of premiums-to-equity was not significant, even though the overall F-statistic was significant (see Appendix C, Table C.2). Size was positively correlated with liabilitiesto-equity and premiums-to-equity, indicating that bigger companies tend to be more leveraged (see Appendix C, Tables C.3, C.4).

With size and ROTE as controls in the regressions, the directional relationships between the leverage and market value variables remained the same, with only slight differences in the magnitude of coefficients. However, when size and ROTE were added to the market-to-book regression with liabilities-to-equity, the individual 
coefficient for the liabilities-to-equity was no longer significant at the 5 per cent level. The overall F-statistic was still significant (Appendix D, Tables D.1, D.2). Given these results, the best model with controls for market-to-book is:

$$
\begin{aligned}
V_{M B}= & -0.66+L_{\operatorname{Pr} e E} \times 0.24-L_{\operatorname{Pr} e E}^{2} \times 0.02 \\
& +S \times 0.39-S^{2} \times 0.02+R \times 2.83
\end{aligned},
$$

where $V_{M B}=$ Market-to-book, $L_{\operatorname{Pr} e E}=$ Premiums-to-equity, $S=$ Size $\ln$ (assets), $R=\mathrm{ROTE}$.

The regressions with size, ROTE, and liabilities-to-equity had more explanatory power than the regression with the controls and premiums-to-equity, so although both were significant, the best model for price-to-earnings is:

$$
\begin{aligned}
V_{P E}= & 13.53+L_{L E} \times 2.46-L_{L E}^{2} \times 0.15 \\
& +S \times 1.42-R \times 74.11
\end{aligned},
$$

where $\quad V_{P E}=$ Price-to-earnings,$\quad L_{L E}=$ Liabilities-to-equity,$\quad S=$ Size $\ln$ (assets), $R=$ ROTE.

\section{Segmentation by location}

Given potential bias resulting from different accounting standards by countries, we segmented the data into international and U.S. companies. The U.S. had the highest number of companies in the sample (see Table 6). Regressions with price-to-earnings for international firms were similar to those for the whole group, with only a slight change in the magnitude of the coefficients and an increase in the explanatory power of the regressions (see Appendix E, Table E.1). Regressions with market-to-book for international firms were again similar to the whole-set regressions, although in this case the $R$-squares decreased compared with the whole-set regressions (see Appendix E, Table E.2).

The regressions for U.S. companies did produce different results than those for the whole set. For U.S. companies, the first order of premiums-to-equity had a negative coefficient while the second order of premiums-to-equity had a positive coefficient (for regressions with both market value measures) (see Tables 7 and 8). The models indicated by the regressions are plotted with the actual data points in Figures 5 and 6 . In addition, liabilities-to-equity was not significantly correlated with price-to-earnings for U.S. companies (see Table 7). This means the best model for leverage and priceto-earnings is:

$$
V_{P E}^{\mathrm{U} . \mathrm{S} .}=26.59-L_{\operatorname{Pr} e E}^{\mathrm{U} . \mathrm{S} .} \times 16.61+L_{\operatorname{Pr} e E}^{\mathrm{U} . \mathrm{S} .}{ }^{2} \times 7.00,
$$

where $V_{P E}^{\mathrm{U} . S}$. $=$ Price-to-earnings, $L_{\mathrm{PreE}}^{\mathrm{U} . \mathrm{S}}=$ Premiums-to-equity.

Liabilities-to-equity had a negative, linear relationship with market-to-book for U.S. companies (indicated with a plot of the actual data points on Figure 7) rather than the positive, linear relationship indicated by the regression on the whole set (see Table 8). Liabilities-to-equity and premiums-to-equity (both the first and second 
Table 6 Location of incorporation

\begin{tabular}{lc}
\hline Country & $\begin{array}{c}\text { Number of companies } \\
\text { incorporated }^{\text {a }}\end{array}$ \\
\hline U.S. & 33 \\
Thailand & 12 \\
Japan & 7 \\
United Kingdom & 5 \\
South Korea & 5 \\
Canada & 4 \\
Indonesia & 4 \\
Malaysia & 4 \\
Australia & 3 \\
Bermuda & 3 \\
Taiwan & 3 \\
Cayman Islands & 2 \\
Denmark & 2 \\
China & 1 \\
Germany & 1 \\
France & 1 \\
Italy & 1 \\
Mexico & 1 \\
Pakistan & 1 \\
Singapore & 1 \\
Turkey & 1 \\
South Africa & 1 \\
\hline
\end{tabular}

${ }^{\mathrm{a}}$ Out of the full sample of 96 companies.

order) are all significantly correlated when included in a single regression with marketto-book. This regression provides the best fit of the leverage models for market-tobook for U.S. companies:

$$
V_{M B}^{\mathrm{U} . \mathrm{S} .}=1.84-L_{\operatorname{Pr} e E}^{\mathrm{U.S}} * 0.60+L_{\operatorname{Pr} e E}^{\mathrm{U.S} .}{ }^{2} * 0.41-L_{L E}^{\mathrm{U.S} .} * 0.10,
$$

where $V_{M B}^{\mathrm{U} . S}=$ Market-to-book, $L_{\mathrm{Pr} e}^{\mathrm{U} . S}=$ Premiums-to-equity, $L_{L E}^{\mathrm{U} . \mathrm{S}}=$ Liabilities-to-equity.

The regression results based on the U.S. sample are the opposite of what financial theory would predict. Rather than firm value being optimised at a mid-range level of leverage, firm value is minimised at this leverage level. The sample of U.S. companies may be too small (there were 33 U.S. companies) to adequately portray the trade-off between decreased taxes and increased risk of financial distress associated with leverage. Consequently, we would suggest that more weight should be given to the regressions on the whole set of companies. However, the discrepancies between the whole set and U.S. only regressions may be caused by differences between the structure of U.S. and international companies, and the surprising result we found for U.S. companies should be investigated further.

Different accounting standards or tax regulations in the U.S. compared with other countries could cause the observed differences in the models. Requirements for 
Table 7 U.S. companies only-dependent variable: price-to-earnings

\begin{tabular}{|c|c|c|c|c|c|c|c|c|c|c|}
\hline Regression & Independent variable & Coefficient & T-statistic & $P$-value & Intercept & $R$-square & Standard error & $F$-statistic & F-value & $N$ \\
\hline \multirow[t]{2}{*}{13} & Premiums-to-equity & -16.608 & -3.892 & 0.000 & \multirow[t]{2}{*}{26.586} & \multirow[t]{2}{*}{0.053} & \multirow[t]{2}{*}{11.828} & \multirow[t]{2}{*}{7.593} & \multirow[t]{2}{*}{0.001} & \multirow[t]{2}{*}{276} \\
\hline & Premiums-to-equity ${ }^{\wedge} 2$ & 7.004 & 3.674 & 0.000 & & & & & & \\
\hline 15 & Size $\ln$ (assets) & 0.185 & 0.425 & 0.671 & 17.613 & 0.001 & 12.126 & 0.181 & 0.671 & 276 \\
\hline 16 & ROTE & -65.338 & -6.701 & 0.000 & 27.101 & 0.141 & 11.244 & 44.908 & 0.000 & 276 \\
\hline \multirow[t]{3}{*}{17} & ROTE & -68.478 & -7.019 & 0.000 & \multirow[t]{3}{*}{33.371} & \multirow[t]{3}{*}{0.198} & \multirow[t]{3}{*}{10.904} & \multirow[t]{3}{*}{22.379} & \multirow[t]{3}{*}{0.000} & \multirow[t]{3}{*}{276} \\
\hline & Premiums-to-equity & -16.213 & -4.121 & 0.000 & & & & & & \\
\hline & Premiums-to-equity ${ }^{\wedge} 2$ & 7.737 & 4.395 & 0.000 & & & & & & \\
\hline
\end{tabular}

Table 8 U.S. companies only-dependent variable: market-to-book

\begin{tabular}{|c|c|c|c|c|c|c|c|c|c|c|}
\hline Regression & Independent variable & Coefficient & T-statistic & $P$-value & Intercept & $R$-square & Standard error & $F$-statistic & F-value & $N$ \\
\hline 18 & Liabilities-to-equity & -0.098 & -5.673 & 0.000 & 1.797 & 0.097 & 0.589 & 32.182 & 0.000 & 300 \\
\hline \multirow[t]{2}{*}{19} & Liabilities-to-equity & -0.157 & -3.083 & 0.002 & 1.907 & 0.102 & 0.588 & 16.892 & 0.000 & 300 \\
\hline & 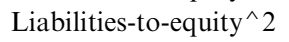 & 0.006 & 1.242 & 0.215 & & & & & & \\
\hline \multirow[t]{2}{*}{20} & Premiums-to-equity & -0.940 & -4.676 & 0.000 & 1.698 & 0.145 & 0.574 & 25.178 & 0.000 & 300 \\
\hline & Premiums-to-equity $^{\wedge} 2$ & 0.534 & 6.018 & 0.000 & & & & & & \\
\hline \multirow[t]{2}{*}{21} & Size $\ln$ (assets) & 0.864 & 3.647 & 0.000 & -2.307 & 0.043 & 0.607 & 6.740 & 0.001 & 300 \\
\hline & $\operatorname{Size}^{\wedge} 2$ & -0.048 & -3.597 & 0.000 & & & & & & \\
\hline \multirow[t]{3}{*}{23} & Premiums-to-equity & -0.598 & -3.017 & 0.003 & 1.842 & 0.238 & 0.543 & 30.801 & 0.000 & 300 \\
\hline & Premiums-to-equity $^{\wedge} 2$ & 0.415 & 4.812 & 0.000 & & & & & & \\
\hline & Liabilities-to-equity & -0.101 & -6.008 & 0.000 & & & & & & \\
\hline \multirow[t]{5}{*}{24} & Premiums-to-equity & -0.481 & -2.617 & 0.009 & -0.738 & 0.426 & 0.474 & 36.189 & 0.000 & 300 \\
\hline & Premiums-to-equity $^{\wedge} 2$ & 0.329 & 4.198 & 0.000 & & & & & & \\
\hline & ROTE & 2.861 & 8.142 & 0.000 & & & & & & \\
\hline & Size $\ln$ (assets) & 0.461 & 2.438 & 0.015 & & & & & & \\
\hline & $\operatorname{Size}^{\wedge} 2$ & -0.023 & -2.192 & 0.029 & & & & & & \\
\hline
\end{tabular}




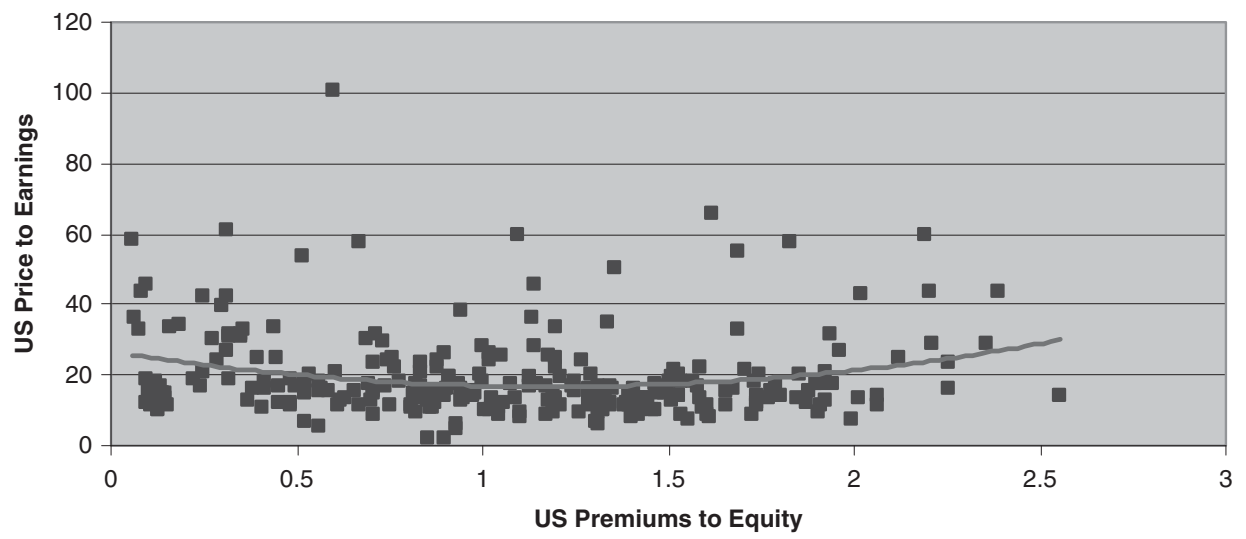

Figure 5. U.S. only: price to earnings as a function of premiums to equity.

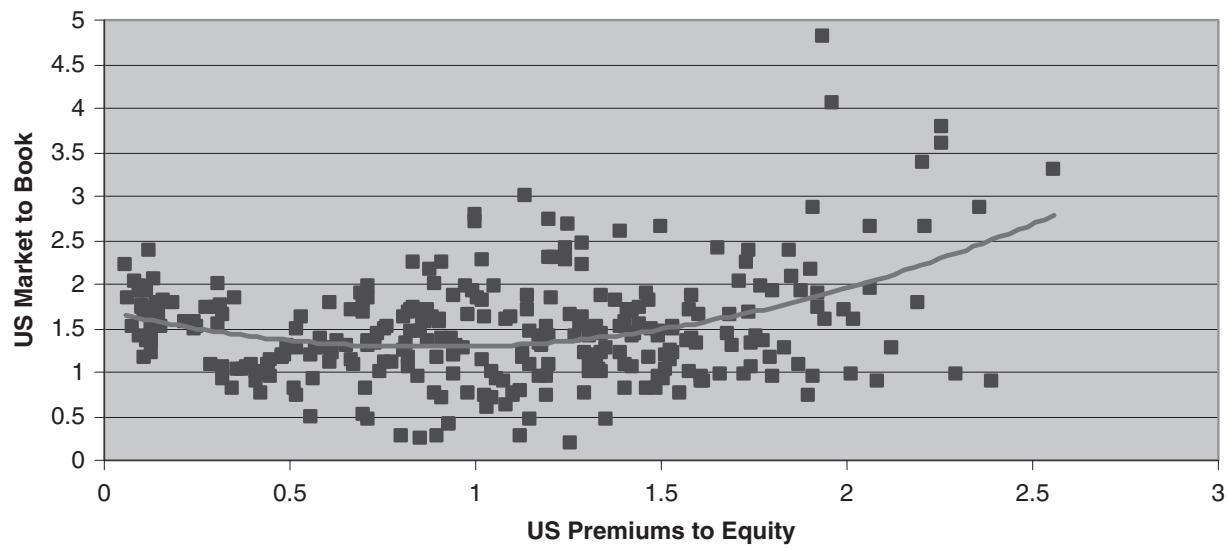

Figure 6. U.S. only: market to book as a function of premiums to equity.

reporting loss reserves differ between U.S. and international companies to allow international firms to deduct more for a similar amount of leverage. For example, in the U.S., losses can only be deducted from income when they occur. On the other hand, some European and Asian countries allow insurers to reserve for future catastrophes and deduct a portion of the estimated reserve each year. This difference provides an incentive to add liabilities for some international firms. In the U.S., since 1987 P-L insurers have only been able to deduct a discounted level of loss reserves with the discount rate arbitrarily based on mid-range U.S. Treasury interest rates. Thus, for accounting purposes loss reserves must be set at the undiscounted level but for tax purposes only a discounted level is considered. This tax difference could explain why the value of insurers in the U.S. might have a negative, linear relationship with liabilities-to-equity. 


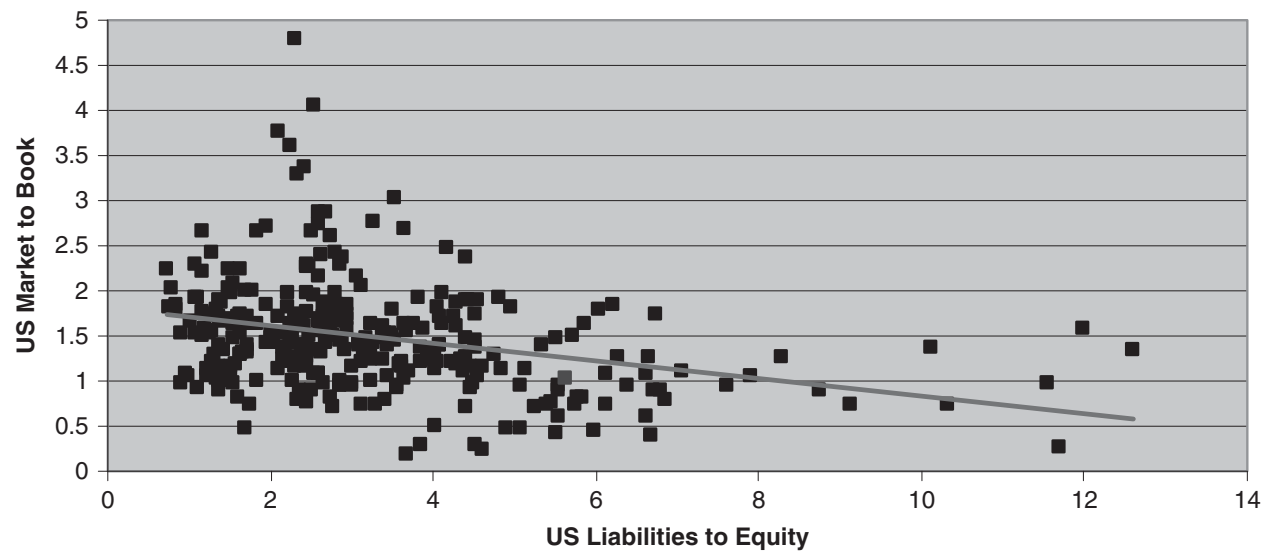

Figure 7. U.S. only: market to book as a function of liabilities to equity.

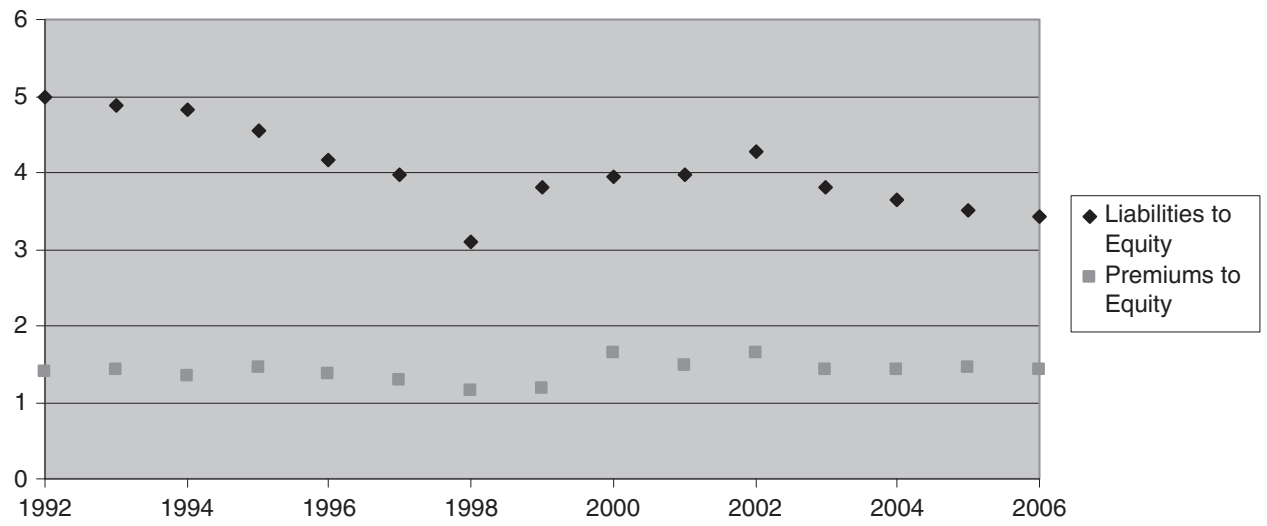

Figure 8. Average leverage.

An explanation for the relationship between premiums-to-equity and market value for U.S. firms could be the standards set by the National Association of Insurance Commissioners (NAIC) in the U.S. According to the NAIC, premiums-to-equity exceeding a 3 to 1 ratio is a signal of potential distress for insurers and may result in increased regulatory scrutiny. This standard may be the reason that the average premiums-to-equity for U.S. companies (1.06) still remains very close to the minimising level indicated by the market value regressions ( 0.88 for market-to-book and 1.19 for price-to-earnings).

\section{Trends}

Now that we have analysed the relationship between capital structure and market value, we will compare the actual industry averages and trends for leverage with the optimal values indicated by the regressions. Over the time period from 1992 to 2006, 


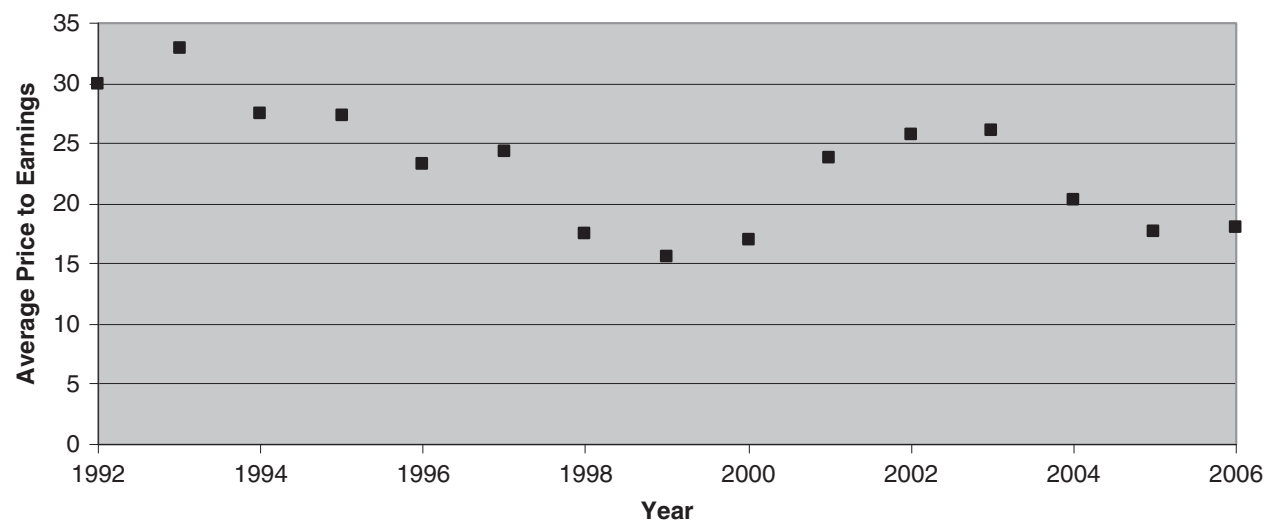

Figure 9. Average price to earnings.

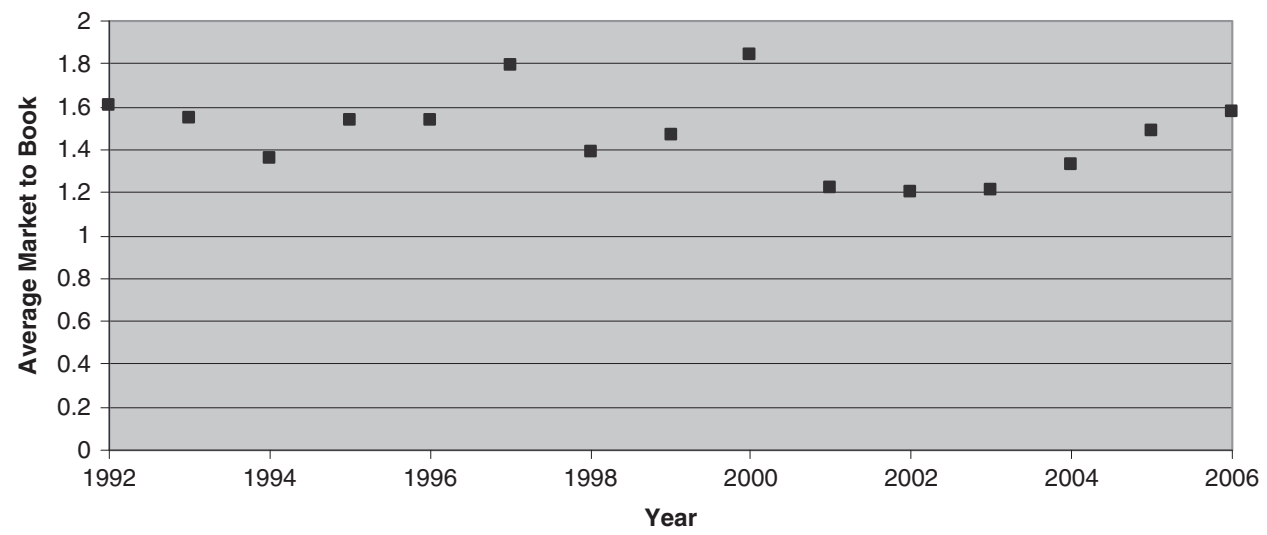

Figure 10. Average market to book.

liabilities-to-equity (leverage) in the industry trended downward, from an average of 4.99 in 1992 to 3.41 in 2006 (see Figure 8). The maximising level indicated by the regression with price-to-earnings was 8.58 , much higher than the average liabilitiesto-equity (3.86). Premiums-to-equity fluctuated around an average of 1.42 for the time period, never reaching the optimal level indicated by either the regression with priceto-earnings or market-to-book (4.02 and 5.70 respectively) (see Figure 8). The average price-to-earnings fluctuated during the period, hitting a low point of 15.92 in 1999. The ratio decreased overall, from 29.94 in 1992 to 17.98 in 2006 (see Figure 9). From 1992 to 2006, market-to-book climbed to two peaks with subsequent drops; the first peak of 1.79 was reached in 1997 and the second of 1.85 was in 2001 (see Figure 10).

\section{Conclusion}

Given these findings and past capital structure research, there is compelling evidence that P-L insurers should actively manage their capital structure to maximise value. 
530

In particular, leverage (both liabilities-to-equity and premiums-to-equity) as well as interest rate risk appear to be the two components of capital structure most closely tied to market value. Management should consider indications from this and past studies when making capital structure decisions. We found that both market value measures increased and then decreased with premiums-to-equity, indicating a maximising level. Liabilities-to-equity and price-to-earnings exhibited the same relationship. All three of these combinations are evidence of traditional capital structure theory. Liabilitiesto-equity had a positive, linear relationship with market-to-book.

The regressions over the whole set seemed to indicate that P-L insurers are underleveraged by both the financial and insurance measures for leverage. However, the market reward for leverage may have changed dramatically following the credit crisis of 2008 in which many financial institutions required substantial capital infusions. P-L management should carefully consider their leverage level because of its relationship with market value, but the level should be analysed in light of recent market events.

Surplus duration is another component of capital structure that impacted marketto-book; it exhibited a negative, linear relationship. This finding suggests that P-L insurers should hedge their interest rate risk to increase market value. However, each firm should analyse this issue further because of the small sample size used for the regressions. Furthermore, given the different results for U.S. vs. international firms, each company should consider the applicable tax and accounting rules when determining its optimal capital structure.

\section{References}

A.M. Best Company (2007) Best's Aggregates and Averages-Property/Casualty-United States \& Canada, Oldwick, NJ: A.M. Best.

Brandes Institute (2008) Liability-Driven Investing and Equity Duration, Brandes Institute Research, January.

Brealey, R.A., Myers, S.C. and Allen, F. (2006) Principles of Corporate Finance, Burr Ridge, IL: McGraw-Hill Irwin.

Cohen, A. (2008) Asymmetric learning in repeated contracting: An empirical study, NBER Working Paper Series, 13752.

Cornell, B. (1999) 'Equity duration, growth options and asset pricing', UC Los Angeles: Finance, http:// escholarship.org/uc/item/3pq609sm.

Cummins, J.D. and Doherty, N.A. (2002) 'Capitalization of the property-liability insurance industry: Overview', Journal of Financial Services Research 21(1, 2): 5-14.

Cummins, J.D. and Lamm-Tennant, J. (1994) 'Capital structure and the cost of equity capital in the property-liability insurance industry', Insurance: Mathematics and Economics 15(2-3): 187-201.

Cummins, J.D. and Nini, G.P. (2002) 'Optimal capital utilization by financial firms: Evidence from the property-liability insurance industry', Journal of Financial Services Research 21(1/2): 15-53.

D'Arcy, S.P. and Doherty, N.A. (1990a) 'Adverse selection, private information, and lowballing in insurance markets', The Journal of Business 63(2): 145-164.

D'Arcy, S.P. and Doherty, N.A. (1990b) 'The aging phenomenon and insurance prices', Proceedings of the Casualty Actuarial Society 76(145): 24-44.

D'Arcy, S.P. and Gorvett, R. (2000) 'Measuring the interest rate sensitivity of loss reserves', Proceedings of The Casualty Actuarial Society 87(166-167): 365-400.

DeAngelo, H. and Masulis, R.W. (1980) 'Optimal capital structure under corporate and personal taxation', Journal of Financial Economics 8(1): 329.

Frank, M.Z. and Goyal, V.K. (2003) 'Testing the pecking order theory of capital structure', Journal of Financial Economics 67(2): 217-248. 
Jensen, M.C. and Meckling, W.H. (1976) 'Theory of the firm: Managerial behavior, agency costs and ownership structure', Journal of Financial Economics 3(4): 305-360.

Long, M.S. and Malitz, I.B. (1983) Investment patterns and financial leverage, NBER Working Paper Series, 1145 .

Mayers, D. and Smith Jr, C.W. (1988) 'Ownership structure across lines of property-casualty insurance', Journal of Law and Economics 31(2): 351-378.

Modigliani, F. and Miller, M.H. (1958) 'The cost of capital, corporation finance, and the theory of investing', The American Economic Review 48(3): 261-297.

Modigliani, F. and Miller, M.H. (1963) 'Corporate income taxes and the cost of capital: A correction', The American Economic Review 53(3): 433-443.

Myers, S.C. (1977) 'The determinants of corporate borrowing', Journal of Financial Economics 5(2): 147-175.

Myers, S.C. (1984) 'The capital structure puzzle', The Journal of Finance 39(3): 575-592.

Myers, S.C. and Majluf, N.S. (1984) 'Corporate financing and investment decisions when firms have information that investors do not have', Journal of Financial Economics 13(2): 187-221.

Robichek, A.A. and Myers, S.C. (1966) 'Problems in the theory of optimal capital structure', The Journal of Financial and Quantitative Analysis 1(2): 1-35.

Staking, K.B. and Babbel, D.F. (1995) 'The relation capital structure, interest rate sensitivity, and market value in the property-liability insurance industry', Journal of Risk and Insurance 62(4): 690-718.

Staking, K.B. and Babbel, D.F. (1997) 'Insurer surplus duration and market value revisited', Journal of Risk and Insurance 64(4): 739-743.

\section{Appendix A}

Company representation by year

Table A.1 Company representation by year

\begin{tabular}{|c|c|c|}
\hline Year & $\begin{array}{c}\text { Number of companies with } \\
\text { all data points }\end{array}$ & $\begin{array}{c}\text { Percentage of companies with } \\
\text { all data points }{ }^{\mathrm{b}}(\%)\end{array}$ \\
\hline 1992 & 20 & 21 \\
\hline 1993 & 21 & 22 \\
\hline 1994 & 23 & 24 \\
\hline 1995 & 24 & 25 \\
\hline 1996 & 32 & 33 \\
\hline 1997 & 40 & 42 \\
\hline 1998 & 64 & 67 \\
\hline 1999 & 66 & 69 \\
\hline 2000 & 72 & 75 \\
\hline 2001 & 75 & 78 \\
\hline 2002 & 78 & 81 \\
\hline 2003 & 81 & 84 \\
\hline 2004 & 86 & 90 \\
\hline 2005 & 88 & 92 \\
\hline 2006 & 86 & 90 \\
\hline
\end{tabular}

${ }^{a}$ Not all these companies had a statistic for surplus duration; those regressions were run on a smaller set.

${ }^{\mathrm{b}}$ There were a total of 96 companies with at least one data point. 


\section{Appendix B}

Profitability regressions

Table B.1 Profitability-dependent variable: market-to-book

\begin{tabular}{|c|c|c|c|c|c|c|c|c|c|c|}
\hline Regression & Independent variable & Coefficient & T-statistic & $P$-value & Intercept & $R$-square & Standard error & $F$-statistic & F-value & $N$ \\
\hline 34 & ROTE & 2.904 & 5.085 & 0.000 & 1.154 & 0.029 & 1.719 & 25.853 & 0.000 & 856 \\
\hline \multirow[t]{3}{*}{35} & ROTE & 2.889 & 5.089 & 0.000 & 0.836 & 0.046 & 1.707 & 13.629 & 0.000 & 856 \\
\hline & Premiums-to-equity & 0.314 & 3.806 & 0.000 & & & & & & \\
\hline & Premiums-to-equity^${ }^{\wedge} 2$ & -0.028 & -3.577 & 0.000 & & & & & & \\
\hline \multirow[t]{2}{*}{36} & ROTE & 3.050 & 5.347 & 0.000 & 0.940 & 0.040 & 1.711 & 17.682 & 0.000 & 856 \\
\hline & Liabilities-to-equity & 0.052 & 3.043 & 0.002 & & & & & & \\
\hline
\end{tabular}

Table B.2 Profitability-dependent variable: price-to-earnings

\begin{tabular}{|c|c|c|c|c|c|c|c|c|c|c|}
\hline Regression & Independent variable & Coefficient & $T$-statistic & $P$-value & Intercept & $R$-square & Standard error & F-statistic & F-value & $N$ \\
\hline 37 & ROTE & -79.917 & -8.668 & 0.000 & 30.473 & 0.088 & 21.873 & 75.129 & 0.000 & 780 \\
\hline \multirow[t]{3}{*}{38} & ROTE & -81.050 & -8.774 & 0.000 & 26.491 & 0.103 & 21.722 & 29.689 & 0.000 & 780 \\
\hline & Premiums-to-equity & 4.331 & 3.557 & 0.000 & & & & & & \\
\hline & Premiums-to-equity ${ }^{\wedge} 2$ & -0.462 & -3.406 & 0.001 & & & & & & \\
\hline \multirow[t]{3}{*}{39} & Liabilities-to-equity & 4.059 & 6.106 & 0.000 & 20.745 & 0.134 & 21.347 & 39.903 & 0.000 & 780 \\
\hline & 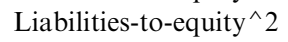 & -0.234 & -5.065 & 0.000 & & & & & & \\
\hline & ROTE & -75.826 & -8.404 & 0.000 & & & & & & \\
\hline
\end{tabular}


Table B.3 Profitability-dependent variable: liabilities-to-equity

\begin{tabular}{llccccccccc}
\hline Regression & Independent variable & Coefficient & T-statistic & P-value & Intercept & R-square & Standard error & F-statistic & F-value & $N$ \\
\hline 40 & ROTE & -2.812 & -2.465 & 0.014 & 4.142 & 0.007 & 3.434 & 6.074 & 0.014 & 856
\end{tabular}

Table B.4 Profitability-dependent variable: premiums-to-equity

\begin{tabular}{lccccccccccc}
\hline Regression & Independent variable & Coefficient & T-statistic & P-value & Intercept & R-square & Standard error & F-statistic & F-value & $N$ \\
\hline 41 & ROTE & 0.741 & 1.432 & 0.153 & 1.349 & 0.002 & 1.559 & 2.050 & 0.153 & 856 \\
\hline
\end{tabular}

\section{Appendix C}

Regressions with size as a control

Table C.1 Size-dependent variable: market-to-book

\begin{tabular}{|c|c|c|c|c|c|c|c|c|c|c|}
\hline Regression & Independent variable & Coefficient & T-statistic & $P$-value & Intercept & $R$-square & Standard error & $F$-statistic & F-value & $N$ \\
\hline \multirow[t]{2}{*}{42} & Size $\ln$ (assets) & 0.537 & 3.402 & 0.001 & -0.665 & 0.020 & 1.728 & 8.791 & 0.000 & 856 \\
\hline & $\operatorname{Size}^{\wedge} 2$ & -0.031 & -2.967 & 0.003 & & & & & & \\
\hline & Size 2 & -0.028 & -2.613 & 0.009 & & & & & & \\
\hline & Premiums-to-equity & 0.246 & 2.857 & 0.004 & & & & & & \\
\hline & Premiums-to-equity $^{\wedge} 2$ & -0.024 & -2.892 & 0.004 & & & & & & \\
\hline \multirow[t]{2}{*}{44} & Size $\ln$ (assets) & 0.056 & 1.958 & 0.050 & 0.912 & 0.012 & 1.735 & 5.211 & 0.006 & 856 \\
\hline & Liabilities-to-equity & 0.026 & 1.310 & 0.191 & & & & & & \\
\hline
\end{tabular}


Table C.2 Size-dependent variable: price-to-earnings

\begin{tabular}{|c|c|c|c|c|c|c|c|c|c|c|}
\hline Regression & Independent variable & Coefficient & T-statistic & $P$-value & Intercept & $R$-square & Standard error & $F$-statistic & F-value & $N$ \\
\hline 45 & Size & 2.387 & 6.996 & 0.000 & 2.985 & 0.059 & 22.217 & 20.017 & 0.000 & 780 \\
\hline \multirow[t]{2}{*}{46} & Size & 2.108 & 0.997 & 0.319 & 3.913 & 0.059 & 22.231 & 24.449 & 0.000 & 780 \\
\hline & $\mathrm{Size}^{\wedge} 2$ & 0.019 & 0.133 & 0.894 & & & & & & \\
\hline \multirow[t]{3}{*}{47} & Liabilities-to-equity & 2.635 & 3.100 & 0.002 & 3.240 & 0.071 & 22.107 & 19.713 & 0.000 & 780 \\
\hline & Liabilities-to-equity^ 2 & -0.165 & -3.036 & 0.002 & & & & & & \\
\hline & Size $\ln$ (assets) & 1.615 & 3.658 & 0.000 & & & & & & \\
\hline \multirow[t]{2}{*}{48} & Size $\ln$ (assets) & 2.322 & 6.623 & 0.000 & 2.182 & 0.067 & 22.156 & 18.494 & 0.000 & 780 \\
\hline & Premiums-to-equity $^{\wedge} 2$ & -0.307 & -2.187 & 0.029 & & & & & & \\
\hline
\end{tabular}

Table C.3 Size-dependent variable: liabilities-to-equity

\begin{tabular}{llcccccccccc}
\hline Regression & Independent variable & Coefficient & T-statistic & $P$-value & Intercept & R-square & Standard error & F-statistic & F-value & $N$ \\
\hline 49 & Size & 0.705 & 16.003 & 0.000 & -1.551 & 0.231 & 3.023 & 256.100 & 0.000 & 856 \\
\hline
\end{tabular}

Table C.4 Size-dependent variable: premiums-to-equity

\begin{tabular}{llcccccccccc}
\hline Regression & Independent variable & Coefficient & T-statistic & P-value & Intercept & R-square & Standard error & F-statistic & F-value & $N$ \\
\hline 50 & Size & 0.101 & 4.474 & 0.000 & 0.651 & 0.023 & 1.543 & 20.017 & 0.000 & 856 \\
\hline
\end{tabular}




\section{Appendix D}

Regressions with size and profitability controls

Table D.1 Size and profitability-dependent variable: price-to-earnings

\begin{tabular}{|c|c|c|c|c|c|c|c|c|c|c|}
\hline Regression & Independent variable & Coefficient & $T$-statistic & $P$-value & Intercept & $R$-square & Standard error & F-statistic & F-value & $N$ \\
\hline \multirow[t]{4}{*}{51} & Size $\ln$ (assets) & 2.012 & 5.944 & 0.000 & 12.118 & 0.142 & 21.256 & 32.086 & 0.000 & 780 \\
\hline & ROTE & -75.045 & -8.250 & 0.000 & & & & & & \\
\hline & Premiums-to-equity & 2.609 & 2.128 & 0.034 & & & & & & \\
\hline & Premiums-to-equity^ 2 & -0.320 & -2.377 & 0.018 & & & & & & \\
\hline \multirow[t]{3}{*}{52} & Liabilities-to-equity & 2.464 & 3.021 & 0.003 & 13.526 & 0.146 & 21.209 & 33.097 & 0.000 & 780 \\
\hline & Liabilities-to-equity^$\wedge 2$ & -0.152 & -2.904 & 0.004 & & & & & & \\
\hline & Size $\ln$ (assets) & 1.415 & 3.334 & 0.001 & & & & & & \\
\hline
\end{tabular}

Table D.2 Size and profitability-dependent variable: market to book

\begin{tabular}{|c|c|c|c|c|c|c|c|c|c|c|}
\hline Regression & Independent variable & Coefficient & $T$-statistic & $P$-value & Intercept & $R$-square & Standard error & $F$-statistic & F-value & $N$ \\
\hline \multirow[t]{5}{*}{53} & Size $\ln$ (assets) & 0.388 & 2.423 & 0.016 & \multirow[t]{5}{*}{-0.655} & \multirow[t]{5}{*}{0.058} & \multirow[t]{5}{*}{1.698} & \multirow[t]{5}{*}{10.374} & \multirow[t]{5}{*}{0.000} & \multirow[t]{5}{*}{856} \\
\hline & $\mathrm{Size}^{\wedge} 2$ & -0.022 & -2.048 & 0.041 & & & & & & \\
\hline & ROTE & 2.829 & 4.967 & 0.000 & & & & & & \\
\hline & Premiums-to-equity & 0.243 & 2.864 & 0.004 & & & & & & \\
\hline & Premiums-to-equity $^{\wedge} 2$ & -0.024 & -2.981 & 0.003 & & & & & & \\
\hline \multirow[t]{3}{*}{54} & ROTE & 2.891 & 5.042 & 0.000 & \multirow[t]{3}{*}{-0.545} & \multirow[t]{3}{*}{0.050} & \multirow[t]{3}{*}{1.704} & \multirow[t]{3}{*}{11.122} & \multirow[t]{3}{*}{0.000} & \multirow[t]{3}{*}{856} \\
\hline & Size $\ln$ (assets) & 0.399 & 2.492 & 0.013 & & & & & & \\
\hline & Liabilities-to-equity & 0.028 & 1.419 & 0.156 & & & & & & \\
\hline
\end{tabular}




\section{Appendix E}

Capital structure regressions for international companies only

Table E.1 International companies only-dependent variable: price-to-earnings

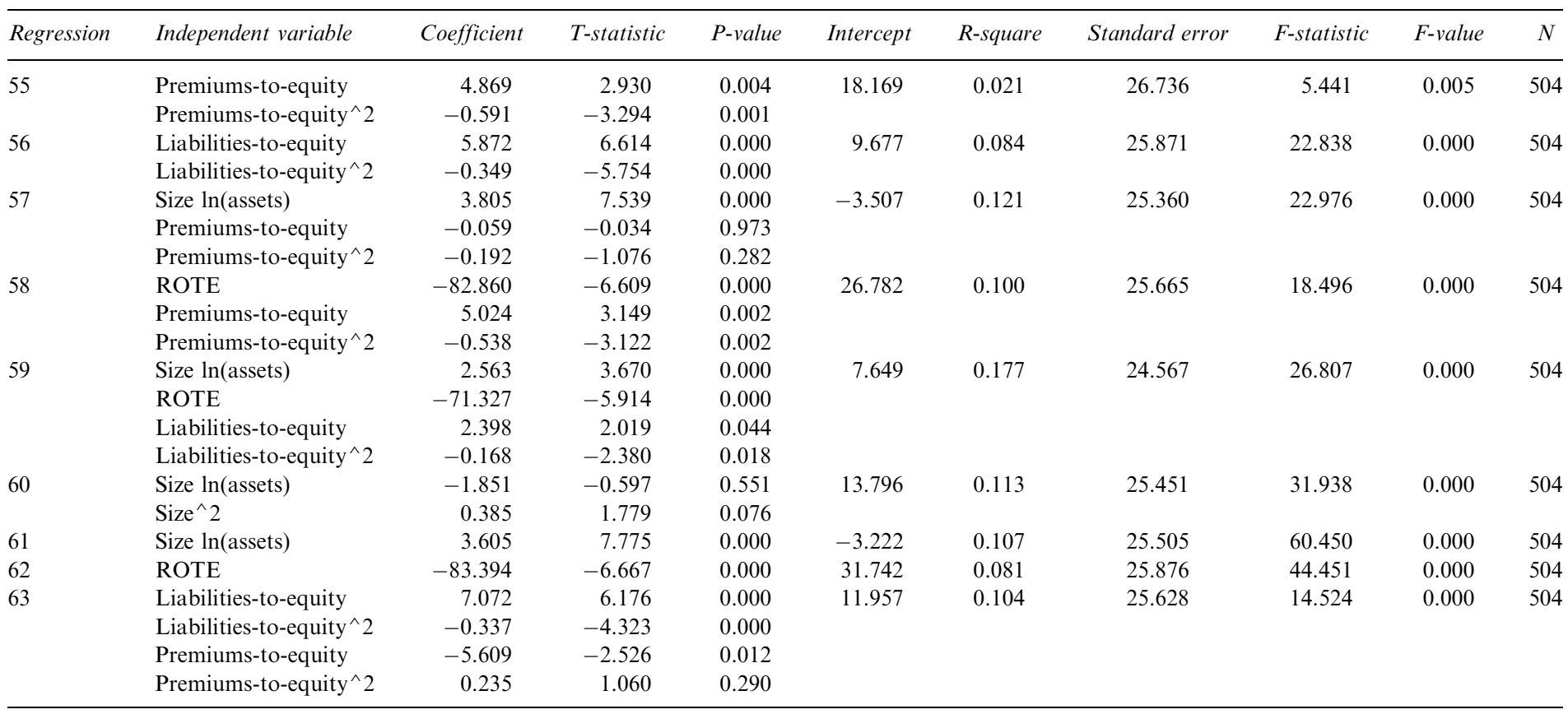


Table E.2 International companies only-dependent variable: market-to-book

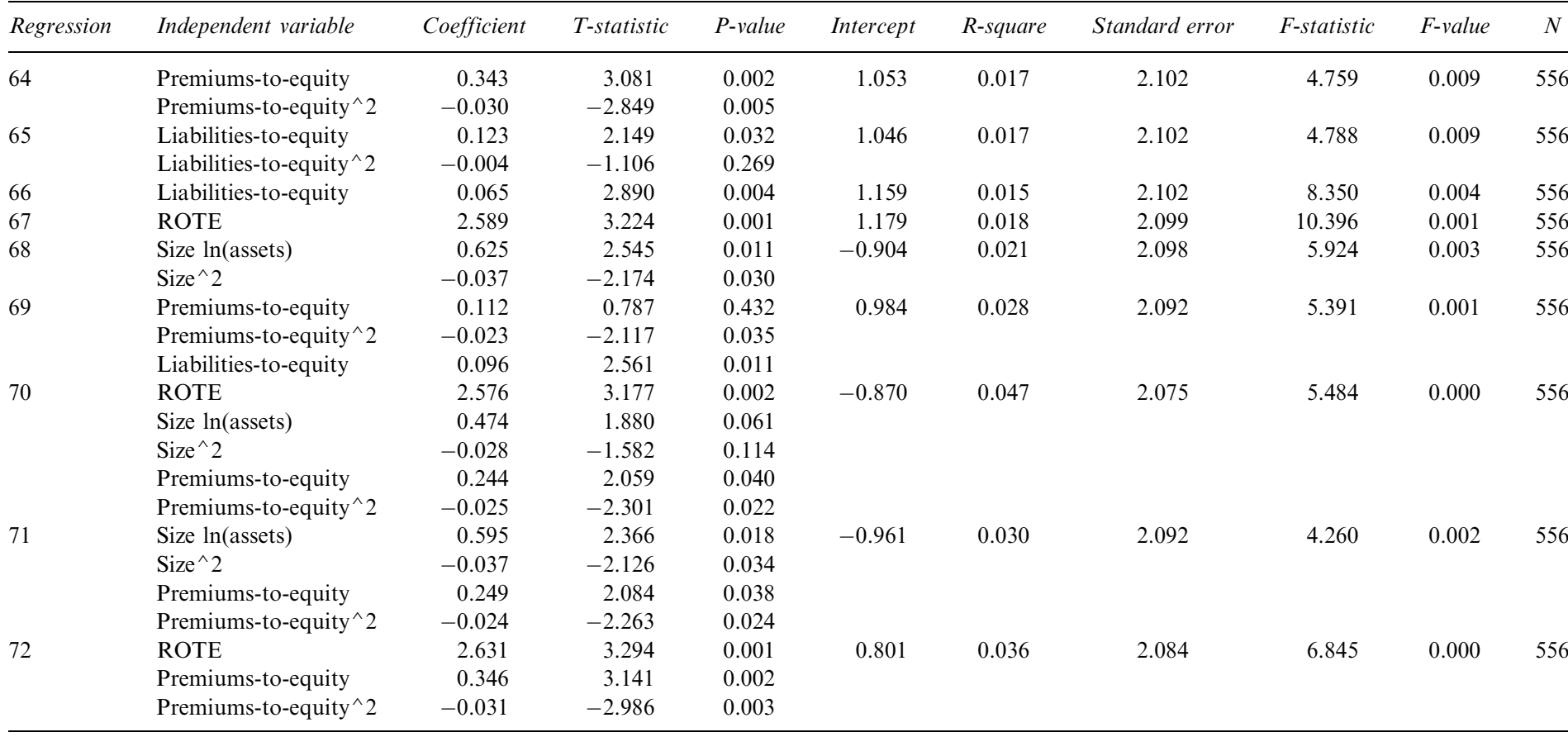




\section{About the Authors}

Stephen P. D'Arcy is the Robitaille Endowed Chair in Risk and Insurance at California State University, Fullerton and Professor Emeritus of Finance at the University of Illinois at Urbana-Champaign. He is a Fellow of the Casualty Actuarial Society, a member of the American Academy of Actuaries, Past-President of the American Risk and Insurance Association and Past-President of the Casualty Actuarial Society.

Teresa Lwin is a PhD student in Finance at the Chicago Booth School of Business. Her research interests include empirical corporate finance, non-profit finance and banking. She graduated with honours in Finance and a minor in Mathematics from the University of Illinois at Urbana-Champaign in 2008. 